\title{
Characterization of a Phytoplasma Associated with Cabbage Yellows in Iran
}

\author{
M. Salehi, Agricultural Research Center of Fars, Zarghan, Iran; and K. Izadpanah and M. Siampour, Department \\ of Plant Protection, College of Agriculture, Shiraz University, Shiraz, Iran
}

\begin{abstract}
Salehi, M., Izadpanah, K., and Siampour, M. 2007. Characterization of a phytoplasma associated with cabbage yellows in Iran. Plant Dis. 91:625-630.

In 2001, a disease tentatively named Iranian cabbage yellows (ICY) was observed in cabbage fields of Zarghan (Fars Province, Iran). The major symptoms of the disease were yellowing, little leaves, plant stunting, opening of the head, and proliferation of the buds at the base of the stem into a witches'-broom. Among leafhoppers collected in cabbage fields, only Circulifer haematoceps transmitted the ICY agent. The disease agent was transmitted by the leafhopper from cabbage to cabbage, cauliflower, rape, and periwinkle, causing phytoplasma-type symptoms in these plants. Polymerase chain reaction (PCR) using phytoplasma-specific primer pair P1/P7 and nested PCR using P1/P7 and R16F2n/R16R2 primer pairs amplified products of expected size (1.8 and $1.2 \mathrm{~kb}$, respectively) from symptomatic cabbage plants. Both restriction fragment length polymorphism (RFLP) of nested PCR products $(1.2 \mathrm{~kb})$ and phylogenetic analyses of $16 \mathrm{~S}-23 \mathrm{~S}$ rDNA spacer region sequence indicated that the ICY phytoplasma had the closest relationship to subgroup A members of the clover proliferation group, including beet leafhopper-transmitted virescence agent, 'Candidatus Phytoplasma trifolii', Columbia Basin potato purple top phytoplasma, and vinca virescence phytoplasma. Cabbage is reported as a new natural host to the 16SrVI group of phytoplasmas.
\end{abstract}

Many vegetable crops are subject to infection by phytoplasmas of the aster yellows group (16SrI) $(23,30)$. In cabbage, phytoplasmal diseases have been reported from Europe $(3,24,34)$ and the United States $(19,21,22)$. Phytoplasmas belonging to the $16 \mathrm{SrI}-\mathrm{B}$ group have been found associated with the disease. Several leafhopper species have been reported as vectors of these phytoplasmas $(25,26)$. In the United States, the principal vectors of cabbage yellows phytoplasma are Macrosteles fascifrons, M. quadrilineatus, Scaphytopius irroratus, and Ceratagallia $a b$ rupta $(5,19,23,37)$.

Cabbage (Brassica oleracea var. capitata) is an economically important vegetable crop in Iran. In 2001, a disease tentatively named Iranian cabbage yellows (ICY) seriously damaged cabbage crops in Zarghan, Fars Province. Up to 50\% infection was observed in certain fields. The present study reports association of a phytoplasma with the ICY disease, vector identification, partial host range determination, and partial characterization of the

Corresponding author: K. Izadpanah

E-mail: izadpana@shirazu.ac.ir

Accepted for publication 18 October 2006.

doi: 10.1094/PDIS-91-5-0625

(C) 2007 The American Phytopathological Society disease agent. A preliminary report on the occurrence of the disease has been published (27).

Differentiation of phytoplasmas is largely based on the analysis of $16 \mathrm{~S}$ rDNA. However, the 16S-23S spacer region (SR) is also a reliable and convenient phylogenetic marker $(18,32)$. Phylogenetic trees derived from SR sequences differentiated phytoplasmas into groups that were in complete agreement with the grouping previously established from full-length analysis of $16 \mathrm{~S}$ rRNA gene sequences $(9,12,15,18,31,33)$. The SR is less conserved than $16 \mathrm{~S}$ rRNA gene and could have greater use in differentiation of closely related phytoplasmas than the fulllength 16S rRNA gene (32). In the present work, sequence of the SR was used to determine the taxonomic position of the ICY phytoplasma.

\section{MATERIALS AND METHODS}

Source of the ICY phytoplasma. A naturally infected cabbage plant with typical yellows symptoms was selected in a severely infected cabbage field in Zarghan (25 km north of Shiraz) and used as the source of the ICY agent in various experiments. The ICY agent was maintained and propagated in both cabbage and a red line of periwinkle (Catharanthus roseus) by periodic inoculation using insect vector Circulifer haematoceps. Other samples of diseased or symptomless cabbage plants were collected in Zarghan and used in the polymerase chain reaction (PCR) assay.

Vector search and host range studies. Insects were collected from a cabbage field showing symptoms in Zarghan using an insect collection net and then sorted by their gross morphology. Insects of each group were subjected to nested PCR to identify those carrying phytoplasma. The species positive for phytoplasma by PCR were tested for the ability to transmit the ICY agent. Fertilized females of species positive for phytoplasmas by PCR were individually transferred to infected or healthy cabbage plants for egg deposition and subsequent establishment of inoculative or noninoculative vector colonies. Colonies were regarded as noninoculative if they did not transmit the disease agent and were negative for phytoplasma by PCR. Young adults from inoculative colonies were transferred (10 insects per plant) to 1-month-old healthy cabbage plants. Alternatively, insects collected in infected cabbage fields were placed in groups of 20 in cages containing four pots, each pot with five healthy cabbage plants, to test their transmission ability immediately after field collection. In host range studies, 10 inoculative vector insects per plant were caged on healthy seedlings of alfalfa (Medicago sativa), cauliflower (Brassica oleracea var. botrytis), clover (Trifolium repens), periwinkle (Catharanthus roseus), rape (Brassica napus), and potato (Solanum tuberosum). In all experiments, 20 young plants of each species were tested. Inoculation access time was always 2 weeks, after which plants were sprayed with an insecticide and kept under observation in a separate insect-free greenhouse. For back-inoculation, noninoculative vector insects were caged on the tested plants for 10 days and transferred to healthy cabbage seedlings in groups of 10 for 4 weeks.

All plants used in this study were grown from seed, and plastic cages were used to maintain insects on test plants.

DNA extraction and PCR amplification. Total nucleic acid was extracted from half a gram of fresh midrib tissue of diseased or healthy cabbage plants using a phytoplasma enrichment procedure (1). Total nucleic acid was extracted from the leafhoppers using a modified hot cetyltrimethyl ammonium bromide (CTAB) 
extraction method (8). Insects of each species were ground in batches of three in 1.5-ml Eppendorf tubes containing $600 \mu \mathrm{l}$ of preheated $\left(65^{\circ} \mathrm{C}\right)$ CTAB buffer $(2 \%$ CTAB, $100 \mathrm{mM}$ Tris- $\mathrm{HCl}$, pH 8.0, $20 \mathrm{mM}$ EDTA, $1.4 \mathrm{M} \mathrm{NaCl}, 1 \% \mathrm{PVP}, 1 \% 2-$ mercaptoethanol) and incubated at $65^{\circ} \mathrm{C}$ for $20 \mathrm{~min}$. Samples were extracted once with an equal volume of chloroformisoamyl alcohol (24:1). The aqueous phase containing nucleic acid layer was precipitated overnight at $-20^{\circ} \mathrm{C}$ with 0.6 volume of isopropanol. The pellets were washed with $70 \%$ ethanol, vacuum dried, suspended in $100 \mu \mathrm{l}$ of sterile water, and stored at $-20^{\circ} \mathrm{C}$ until use.

In direct PCR, phytoplasma universal primer pair P1/P7 $(7,29)$ was used to amplify an 1,800-bp fragment of the ribosomal operon which includes the $16 \mathrm{~S}$ rRNA gene, the $16 \mathrm{~S}-23 \mathrm{~S}$ intergenic spacer region (SR), and a portion of the $5^{\prime}$ region of the 23S rRNA gene. To increase the sensitivity of assays, a nested PCR was performed using a 1:40 dilution of $\mathrm{P} 1 / \mathrm{P} 7$ primed PCR products as templates and primer pair R16F 2n/R16R2 (11), which yields a 1,200-bp fragment of the $16 \mathrm{~S}$ rRNA gene.

PCR was performed in $50-\mu$ reaction mixtures containing $100 \mathrm{ng}$ of total nucleic acid, $0.4 \mu \mathrm{M}$ of each primer, $0.2 \mu \mathrm{M}$ of each $\mathrm{dNTP}$, and $1 \times$ polymerase buffer. The reaction mixtures were overlaid with $30 \mu \mathrm{l}$ of mineral oil and cycled 35 times with the following parameters: denaturing for $1 \mathrm{~min}$ at $94^{\circ} \mathrm{C}$ ( $2 \mathrm{~min}$ for the first cycle), anneal- ing for $2 \mathrm{~min}$ at $55^{\circ} \mathrm{C}$, and primer extension for $3 \mathrm{~min}$ ( $10 \mathrm{~min}$ in the final cycle) at $72^{\circ} \mathrm{C}$. PCR conditions for the secondround nested PCR were the same except that the annealing temperature was $58^{\circ} \mathrm{C}$. Ten microliters of each PCR product were analyzed by electrophoresis in a $1 \%$ agarose gel in $1 \times$ TBE buffer $(67 \mathrm{mM}$ Tris$\mathrm{HCl}, 22 \mathrm{mM}$ boric acid, $10 \mathrm{mM}$ EDTA, $\mathrm{pH}$ 0.8 ). DNA bands were stained with ethidium bromide and visualized with a UV transilluminator.

Restriction fragment length polymorphism (RFLP) analysis. For RFLP analysis, $8 \mu$ of the nested PCR products amplified with primer pair R16F2n/R16R2 were digested with restriction enzymes $A l u \mathrm{I}$, HaeIII, HhaI, HinfI, HpaII, MseI, RsaI, Sau3AI, ThaI, and TaqI according to the instructions of the manufacturer (Roche, Mannheim, Germany) at $37^{\circ} \mathrm{C}\left(65^{\circ} \mathrm{C}\right.$ for TaqI) overnight. The digests were analyzed by electrophoresis through a $5 \%$ polyacrylamide gel followed by staining with ethidium bromide and visualization of DNA bands with UV transilluminator.

Cloning and sequencing. P1/P7 primed rDNA product from ICY phytoplasma was ligated onto pTZ57R/T vector and cloned into Escherichia coli DH5 $\alpha$ cells using InsT/A clone PCR product Cloning Kit (Fermentas, Vilnius, Lithuania) according to manufacturer's instructions. Presence of the correct insert was confirmed by restriction endonuclease analysis using EcoRI and Pst $\mathrm{I}$ enzymes. Plasmid DNA from cultures of recombinant colonies was puri- fied using a High Pure Isolation Kit (Roche). Sequencing was performed by SEQ LAB (Goettingen, Germany). M13 forward and reverse primers were used as sequencing primers. The 16S-23S rDNA SR was further analyzed by using primers P3 and P7 (29) as markers. A BLAST search was performed to determine the closest phytoplasma relatives of the ICY phytoplasma strain.

Sequence homology and phylogenetic analyses. The SR sequences of the ICY phytoplasma, 30 other phytoplasmas representing 15 phytoplasma groups (Table 1), and Acholeplasma laidlawii as an outgroup were aligned using Clustal X 1.81 (IGBMC, Strasbourg, France). A phylogenetic tree was constructed using the neighbor-joining plot option of Clustal X. The SR sequence homology between strains was evaluated after alignments were generated by using homology matrix distance option of DNAMAN program version 4.02 (Lynon Corporation, Quebec, Canada).

\section{RESULTS AND DISCUSSION}

Vector identification. Five leafhopper species including Balclutha salturella, Empoasca decipiens, Psammotettix striatus, Circulifer haematoceps, and Orosius albicinctus were collected in a yellowsaffected cabbage field. Ten samples of each species were assayed for the presence of phytoplasma by nested PCR, using $\mathrm{P} 1 / \mathrm{P} 7$ followed by $\mathrm{R} 16 \mathrm{~F} 2 \mathrm{n} / \mathrm{R} 16 \mathrm{R} 2$ primer pair. Six samples of C. haematoceps tested

Table 1. Phytoplasmas examined in this study with group designations and GenBank accession numbers of 16S-23S rDNA spacer region sequences

\begin{tabular}{|c|c|c|}
\hline Organism & 16S rRNA group/subgroup & GenBank accession no. \\
\hline Aconitum proliferation $(\mathrm{AcP})$ & 16SrI-A & AF510323 \\
\hline Almond witches'-broom (AlmWB) ('Candidatus Phytoplasma phoenicium') & 16SrIX-B & AF515636 \\
\hline Apple proliferation (AP) ('Candidatus Phytoplasma mali') & $16 \mathrm{SrX}-\mathrm{C}$ & AJ542541) \\
\hline Ash yellows (AY) ('Candidatus Phytoplasma fraxini’) & 16SrVII-A & AF092209 \\
\hline Aster yellows (SAY) & 16SrI-B & AF222063 \\
\hline Beet leafhopper-transmitted virescence agent (BLTVA) & 16SrVI-A & U54987 \\
\hline Bermuda grass white leaf isolate C1 (BGWL-C1) & 16SrXIV-A & AJ550984 \\
\hline Bermuda grass white leaf isolate C2 (BGWL-C2) & 16SrXIV-A & AJ550985 \\
\hline Brinjal little leaf (BLL) & 16SrVI-C & X83431 \\
\hline Iranian cabbage yellows (ICY) & $16 \mathrm{SrVI}$ & DQ195214 \\
\hline Columbia Basin potato purple top (CBPPT) & 16SrVI & AY692279 \\
\hline Clover proliferation (CP) ('Candidatus Phytoplasma trifolii') & 16SrVI-A & AY390261 \\
\hline Clover yellow edge (CYE) & 16SrIII-B & AF175304 \\
\hline Coconut lethal decline (CLD) & 16SrIV-B & U18753 \\
\hline Coconut lethal yellows (LY) & 16SrIV-A & AF024639 \\
\hline European stone fruit yellows (Germany) (ESFY) & $16 \mathrm{SrX}-\mathrm{B}$ & U54988 \\
\hline Faba bean phyllody (FBP) & 16SrII-C & X83432 \\
\hline Fragaria multicipita multiplier disease (FM) & 16SrVI-B & AF036354 \\
\hline Grapevine flavescence doreé (FD) & $16 \mathrm{SrV}-\mathrm{A}$ & X76428 \\
\hline Hibiscus witches'-broom (HibWB) ('Candidatus Phytoplasma brasiliense') & 16SrXV & AF147708 \\
\hline Lilac witches'-broom (LWB3) & 16SrVII-A & AF105317 \\
\hline Lime witches'-broom (LWB) ('Candidatus Phytoplasma aurantifolia') & 16SrII-B & U15442 \\
\hline Loofah witches'-broom (LfWB) & 16SrVIII & L33764 \\
\hline Mexican periwinkle virescence (MPV) & 16SrXIII-A & AF025428 \\
\hline Periwinkle little leaf (PLL) & 16SrVI-C & AF228053 \\
\hline Pigeon pea witches'-broom (PPWB) & 16SrIX-A & AF025427 \\
\hline Potato witches'-broom (PWB) & 16SrVI & AY500818 \\
\hline Rice yellow dwarf (RYD) ('Candidatus Phytoplasma oryzae') & $16 \mathrm{SrXI}$ & D12581 \\
\hline Stolbur (STOL) & $16 \mathrm{SrXII}$ & X76427 \\
\hline Vinca virescence (VV) & $16 \mathrm{SrVI}$ & AY500817 \\
\hline Western X-disease (California) (WX) & 16SrIII-A & L04682 \\
\hline Ziziphus witches'-broom (ZWB) ('Candidatus Phytoplasma ziziphi') & $16 \mathrm{SrV}$ & AY072722 \\
\hline
\end{tabular}


positive (data not shown). Other insect species as well as $C$. haematoceps from noninoculative colonies tested negative. Each species was further evaluated as vectors using groups of 20 leafhoppers collected in the field and directly caged on healthy cabbage plants. Among these leafhoppers, only $C$. haematoceps was able to transmit the ICY phytoplasma to healthy cabbage, and 16 out of 20 cabbage plants exposed to this leafhopper developed symptoms of ICY. Similar results were obtained when noninoculative $C$. haematoceps leafhoppers fed first on yellowsaffected cabbage plants were transferred to healthy cabbage seedlings.

Host range and symptomatology. Field symptoms of ICY consisted of plant yellowing, little leaves, plant stunting, opening of the head, and proliferation of buds at the base of the stem into a witches'-broom (Figs. 1 and 2). Similar symptoms were obtained under greenhouse conditions by vector inoculation of cabbage seedlings (Fig. 3).

Of the plant species tested, cauliflower, periwinkle, and rape were infected at the rate of 90,70 , and $80 \%$, respectively, by the ICY phytoplasma using the leafhopper vector. In periwinkle, ICY phytoplasma caused floral virescence, phyllody, proliferation, small leaves, yellowing, terminal witches'-broom, and stunting. Proliferation of white heads into shoots with small leaves and shortened internodes were obvious symptoms of infection on cauliflower. Inoculation of rape resulted in severe witches'-broom through proliferation of crown buds and severe stunting (Fig. 4). The infection of cauliflower, periwinkle, and rape with ICY phytoplasma was confirmed by back-inoculation to cabbage. Under these conditions alfalfa, clover, and potato were not infected.

PCR amplification. With universal primer pair P1/P7, DNA fragments of approximately $1.8 \mathrm{~kb}$ were amplified from 12 of 15 diseased cabbage plants (data not shown). A $1.2-\mathrm{kb}$ product was obtained from all 15 samples by nested PCR. PCR products were not obtained from asymptomatic control plants collected in the field (Fig. 5).

RFLP analysis. The $\mathrm{R} 16 \mathrm{~F} 2 \mathrm{n} / \mathrm{R} 16 \mathrm{R} 2-$ nested PCR product $(1.2 \mathrm{~kb})$ of ICY phytoplasma was subjected to RFLP analysis (Fig. 6). Comparison of the RFLP pattern with published RFLP patterns of other phytoplasmas $(2,13,22,35,36)$ indicated that ICY phytoplasma was similar to members of clover proliferation (CP), 16SrVI, phytoplasma group. Based on AluI, RsaI, HpaII, MseI, Sau3AI, and HhaI analyses, the ICY phytoplasma was indistinguishable from several isolates of alfalfa witches'-broom, clover proliferation, and potato witches'-broom phytoplasmas, members of $16 \mathrm{~S}$ rVI-A subgroup reported from Canada (19,33). Comparison of RFLP patterns of AluI, HaeIII, HhaI,

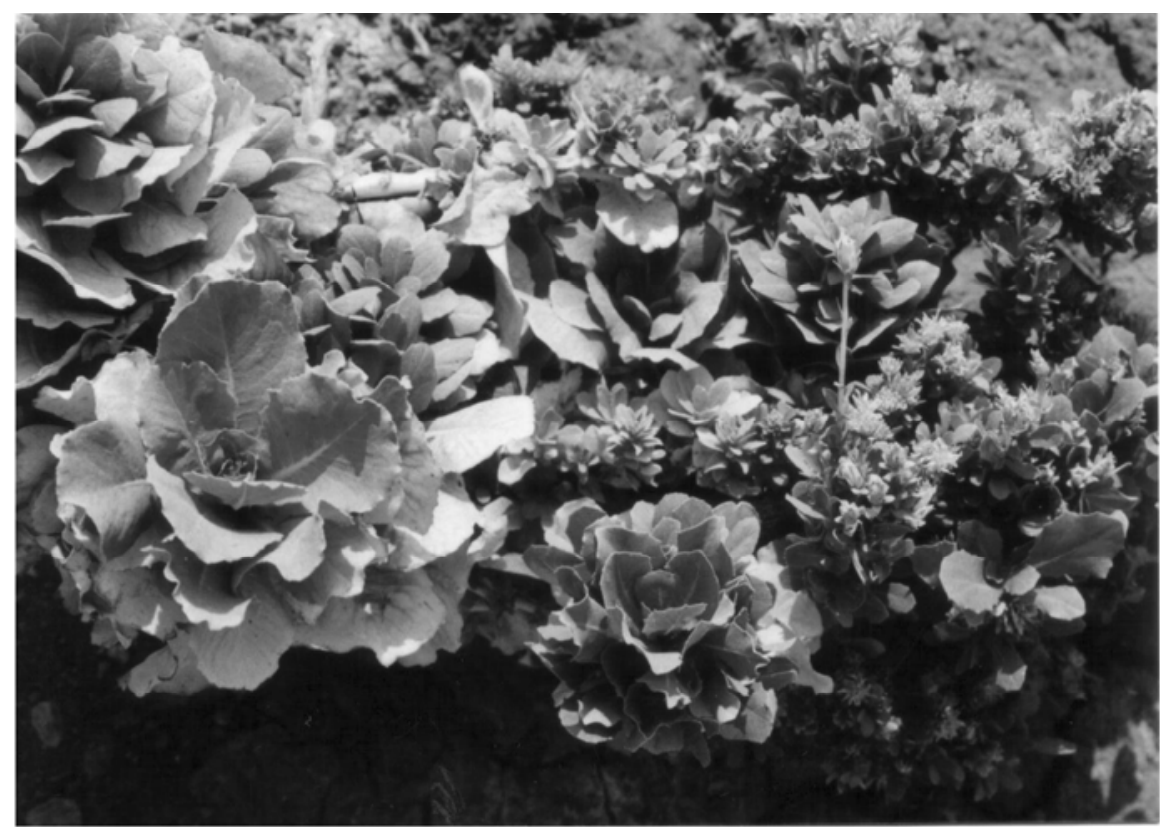

Fig. 1. Little leaf, chlorosis, and stunting in a yellows-affected cabbage field in Zarghan.

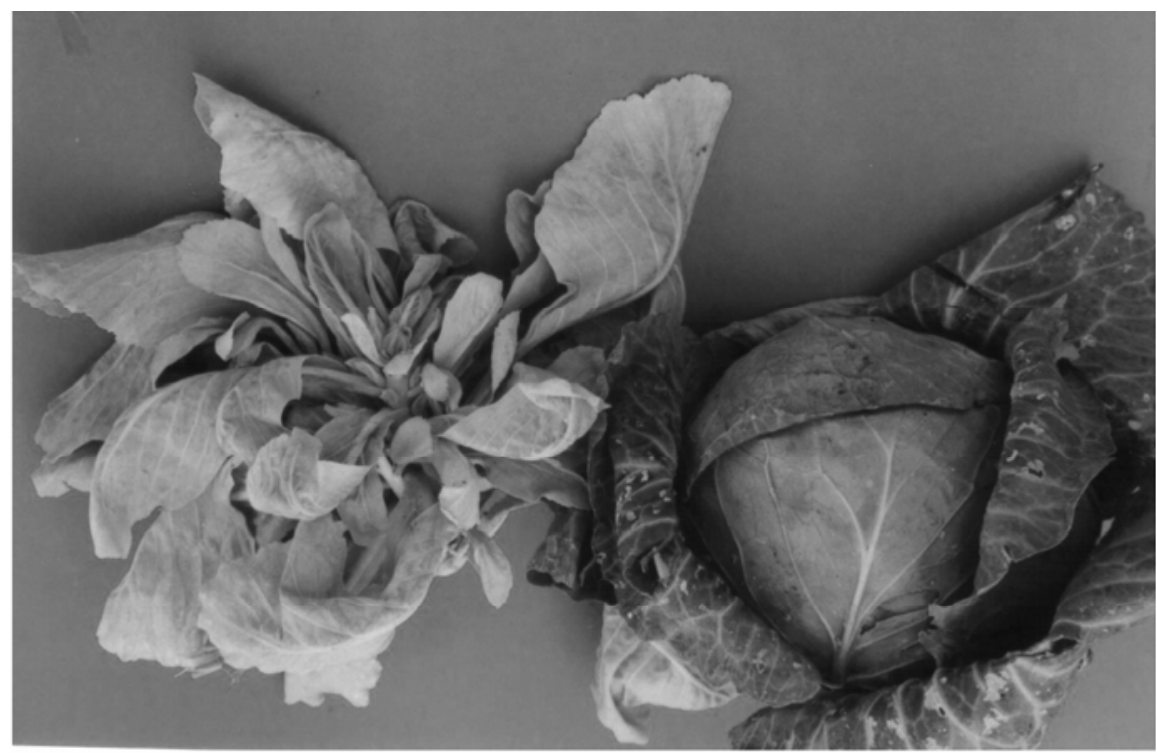

Fig. 2. Opening of the head and proliferation of basal stem buds in a cabbage plant naturally infected with phytoplasma (left) compared with a healthy cabbage plant (right).

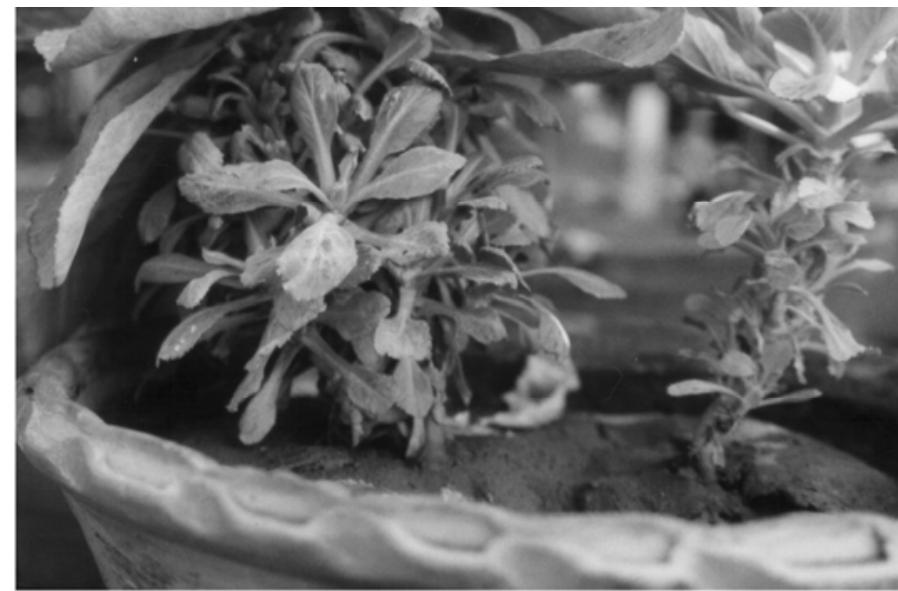

Fig. 3. Proliferation of buds at the base of the stem into shoots with small yellow leaves, shortened internodes, and witches'-broom in two experimentally infected cabbage plants. 


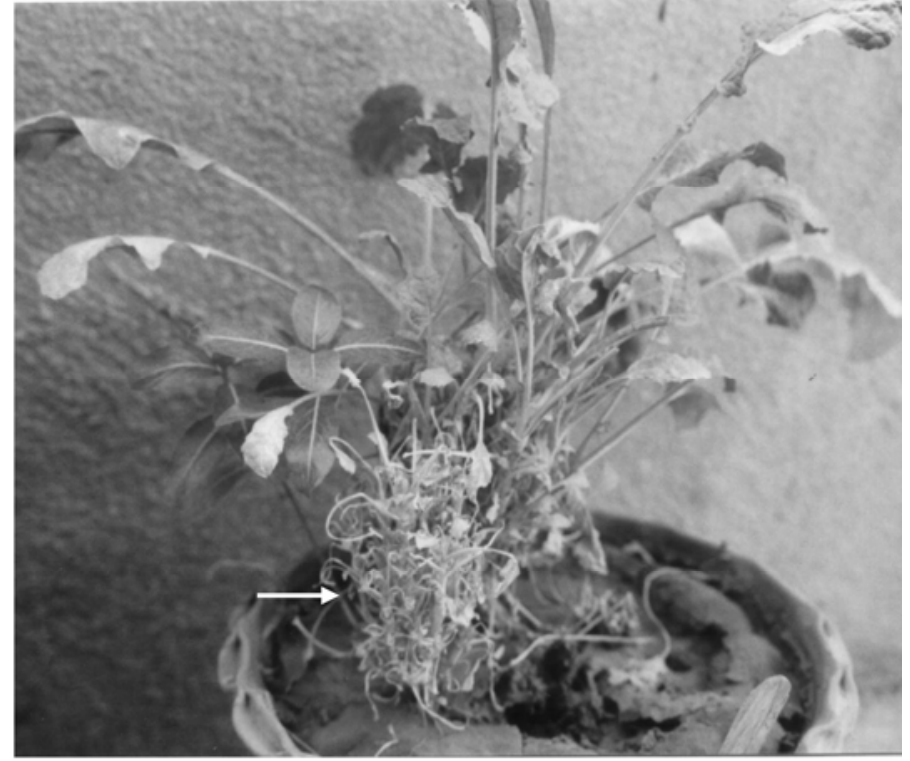

Fig. 4. Severe crown proliferation of rape experimentally infected with Iranian cabbage yellows phytoplasma (arrow).

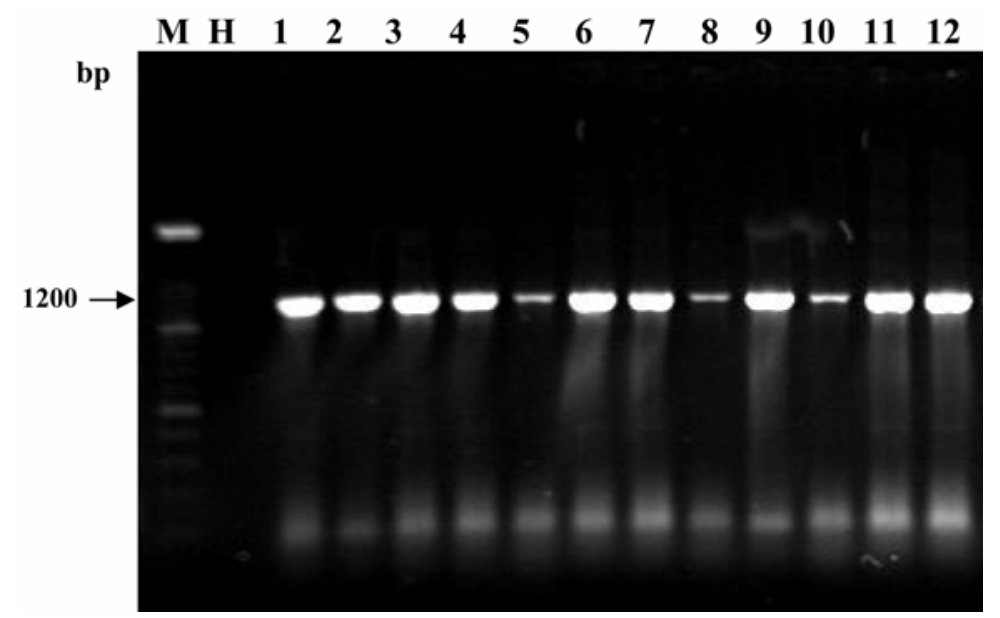

Fig. 5. Electrophoresis pattern of $16 \mathrm{~S}$ rDNA fragment $(1.2 \mathrm{~kb})$ amplified by nested polymerase chain reaction from 12 Iranian cabbage yellows-affected cabbage plants (lanes 1-12). H, healthy plant; M, DNA ladder.

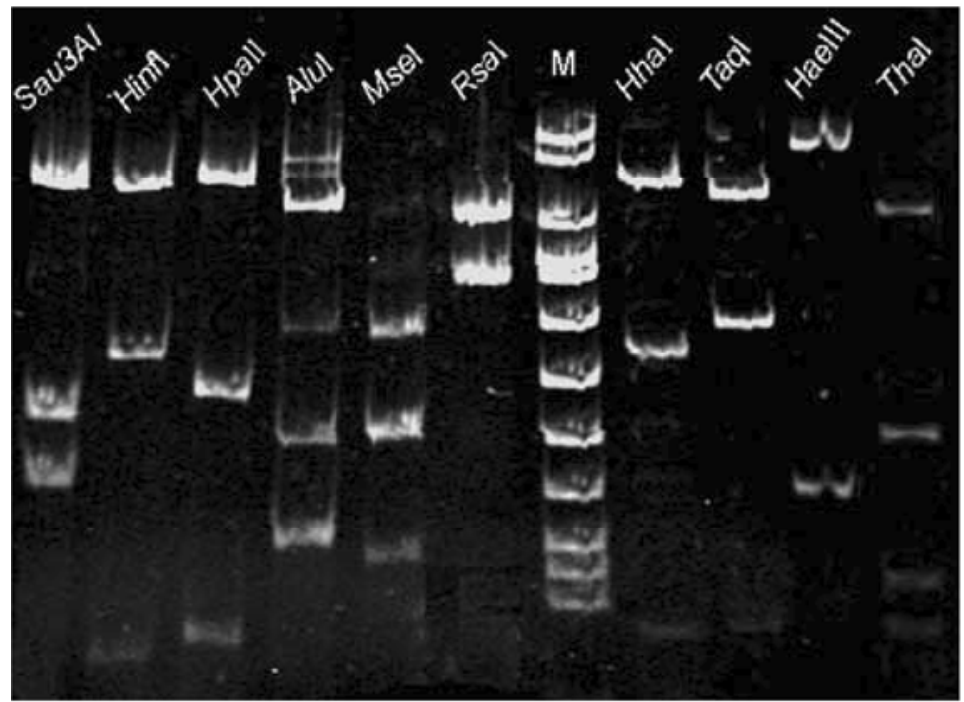

Fig. 6. Restriction fragment length polymorphism (RFLP) profiles in 5\% polyacrylamide gel of $16 \mathrm{~S}$ rDNA amplified by nested polymerase chain reaction from the Iranian cabbage yellows phytoplasma. M, DNA ladder (fragment sizes from top to bottom: 1,114, 900, 692, 501, 489, 404, 320, 242, 190, 147, 124, 110 bp).
HinfI, HapaII, MseI, RsaI, Sau3AI, Taq1, and ThaI enzymes showed that the ICY phytoplasma and a clover proliferation phytoplasma (22) are distinguishable only by Sau3AI.

Sequence homology and phylogenetic analyses. A BLAST search showed that the SR sequence of ICY phytoplasma (Acc. no. DQ195214) shared closest homology with SR sequences from members of the clover proliferation, 16SrVI, group. Among members of CP group, ICY had maximum SR sequence homology $(99.6 \%)$ with beet leafhopper transmitted virescence agent (BLTVA) (16SrVI-A), 'Candidatus Phytoplasma trifolii', Columbia Basin potato purple top (CBPPT) phytoplasma, and vinca virescence (VV) phytoplasma and less homology (97.6\%) with phytoplasma from Fragaria multicipita (16SrVI-B) (FM). SR sequence homology between ICY and other selected members of CP group including brinjal little leaf (BLL), periwinkle little leaf (PLL) (16SrVI-C), and potato witches'-broom (PWB) phytoplasmas was 98.7, 98.7, and $99.2 \%$, respectively. In this analysis, percent homology of the ICY phytoplasma SR sequence with that of aster yellows (SAY), a non-16SrVI related phytoplasma, was $69.7 \%$.

Phylogenetic analysis of SR sequences of 30 phytoplasma strains and Acholeplasma laidlawii as the outgroup yielded a tree (Fig. 7) whose branching order was in general agreement with previous findings $(22,30)$. In this analysis, ICY clustered closely with other known members of the 16SrVI group. Tree branching patterns indicated that the ICY phytoplasma was evolutionarily closest to the BLTVA, ' $\mathrm{Ca}$. Phytoplasma trifolii', and PWB (16SrVIA) phytoplasmas.

Disease symptoms, insect transmission, and a positive reaction in PCR showed that ICY in the Fars Province of Iran was of phytoplasmal etiology. On the basis of molecular analyses, this phytoplasma is related to the clover proliferation group, 16SrVI, and most closely related to BLTVA, 'Ca. Phytoplasma trifolii', and PWB strains, the 16SrVI-A subgroup phytoplasmas (13), as well as to $\mathrm{VV}$ and CBPPT strains. ICY phytoplasma was not transmissible to alfalfa, clover, and potato, hosts of alfalfa witches'-broom agent in Canada, ' $\mathrm{Ca}$. Phytoplasma trifolii', and agents of CBPPT and PWB, respectively. This is supporting evidence that in spite of the similarity of RFLP patterns and more than $99 \%$ sequence homology, ICY phytoplasma is distinct from these phytoplasmas. In other countries, an aster yellowsrelated phytoplasma (16SrI-B) is associated with cabbage yellows $(20,23)$, but no reports were found of cabbage as a host for the $16 \mathrm{SrVI}$ phytoplasma group. Previous studies have also indicated that different phytoplasmas can cause apparently identical symptoms in the same host. Examples 


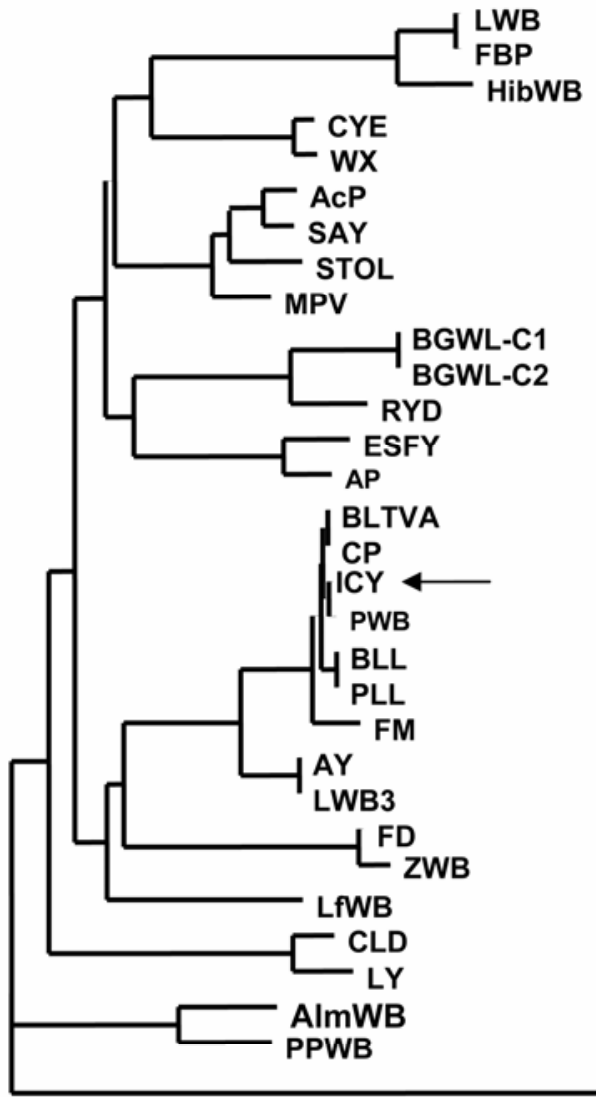

0.1

Fig. 7. Phylogram of 16S-23S rDNA spacer region (SR) sequences of 30 phytoplasmas and Acholeplasma laidlawii (D13260) as the outgroup and the position of Iranian cabbage yellows (ICY) phytoplasma (arrow). Bar, 1 nucleotide substitution per 10 nucleotides. See Table 1 for abbreviations.

are grapevine yellows, big bud of tomato, and disorders of periwinkle (20).

$C$. haematoceps has been previously reported as the vector of several plant pathogens including Beet curly top virus $(14,17)$, Spiroplasma citri $(4,16)$, and sesame phyllody phytoplasma (28). C. haematoceps is reported here for the first time as a natural vector of a clover proliferation-related phytoplasma. At least two members of 16SrVI group (BLTVA and CBPPT phytoplasmas) are transmitted by C. tenellus $(6,10)$. C. haematoceps and the related species $C$. tenellus appear to behave similarly in relation to plant pathogens; therefore, transmission of ICY phytoplasma by $C$. haematoceps also confirms relatedness of this phytoplasma to the clover proliferation group and the close relationship with 16 SrIV-A subgroup. In addition to periwinkle, cauliflower and rape are experimental hosts of the ICY phytoplasma. However, the extent of natural infection of cauliflower and rape by ICY phytoplasma remains to be determined.

\section{ACKNOWLEDGMENTS}

This study was funded in part by the Iranian Chapter of TWAS and Centers of Excellence.

\section{LTERATURE CITED}

1. Ahrens, U., and Seemuller, E. 1992. Detection of DNA of plant pathogenic mycoplasmalike organisms by a polymerase chain reaction that amplifies a sequence of the 16S rRNA gene. Phytopathology 82:828-832.

2. Barros, T. S. L., Davis, R. E., Resende, R. O., and Dally, E. L. 2002. Erigeron witches'broom phytoplasma in Brazil represents new subgroup VII-B in 16S rRNA gene group VII, the ash yellows phytoplasma group. Plant Dis. 86:1142-1148.

3. Bertaccini, A., Davis, R. E., and Lee, I.-M. 1990. Distinction among mycoplasmalike organisms (MLOs) in Gladiolus, Ranunculus, Brassica and Hydrangea through detection with non-radioactive cloned DNA probes. Phytopathol. Mediterr. 29:107-113.

4. Bové, J. M., Fos, A., Lallemand, J., Raie, A., Ali, Y., Ahmed, N., Sailard, C., and Vignault, J. C. 1988. Epidemiology of Spiroplasma citri in the old world. Pages 295-299 in: Proc. Conf. IOCV, 10th, Riverside, CA.

5. Brcak, J. 1979. Leafhopper and planthopper vectors of plant disease agents in central and southern Europe. Pages 97-154 in: Leafhopper Vectors and Plant Disease Agents. K. Maramorosch and K. F. Harris, eds. Academic Press, New York.

6. Crosslin, J. M., Munyaneza, J. E., Jensen, A., and Hamma, P. B. 2005. Association of the beet leafhopper (Homoptera: Cicadellidae) with a clover proliferation group phytoplasma in Columbia Basin of Washington and Oregon. J. Econ. Entomol. 98:279-283.

7. Deng, S. J., and Hiruki, C. 1991. Amplification of 16S rRNA genes from culturable and nonculturable mollicutes. J. Microbiol. Methods 14:53-61.

8. Doyle, J. J., and Doyle, J. I. 1990. Isolation of DNA from fresh plant tissue. Focus 12:13-15.
9. Gibb, K. S., Schneider, B., and Padovan, A. C. 1998. Differential detection and genetic relatedness of phytoplasmas in papaya. Plant Pathol. 47:325-332.

10. Golino, D. A., Oldfield, G. N., and Gumpf, D. J. 1987. Transmission characteristics of the beet leafhopper transmitted virescence agent. Phytopathology 77:954-957.

11. Gundersen, D. E., and Lee, I.-M. 1996. Ultrasensitive detection of phytoplasmas by nestedPCR assays using two universal primer pairs. Phytopathol. Medditerr. 35:144-151.

12. Gundersen, D. E., Lee, I.-M., Rehner, S. A., Davis, R. E., and Kingsbury, D. T. 1994. Phylogeny of mycoplasma-like organisms (phytoplasmas): A basis for their classification. J. Bacteriol. 176:5244-5254.

13. Hiruki, C., and Wang, K. 2004. Clover proliferation phytoplasma: Candidatus Phytoplasma trifolii. Int. J. Syst. Evol. Microbiol. 54:13491353.

14. Kaur, P., Bindra, O. S., and Singh, S. 1971. Biology of Circulifer opacipennis, Lethierr., a leafhopper vector of sugar beet curly top. Indian J. Agric. Sci. 41:1-10.

15. Kenyon, L., Harrison, N. A., Ashburner, G. R., Boa, E. R., and Richardson, P. A. 1998. Detection of a pigeon pea witches' broom related phytoplasma in trees of Gliricidia sepium affected by little-leaf disease in Central America. Plant Pathol. 47:671-680.

16. Kersting, U., Baspinar, U. H., Cinar, A., Sengonea, C., and Uygun, N. 1993. New findings on the epidemiology of Spiroplasma citri in the eastern Mediterranean region of Turkey. Pages 336-341 in: Proc. Conf. IOCV, 12th, Riverside, CA.

17. Kheyri, M., and Alimoradi, I. 1969. The leafhoppers of sugar beet in Iran and their role in curly top virus disease. Sugar Beet Seed Inst. Karaj Entomol. Res. Div., Tehran Iran.

18. Kirkpatrick, B. C., Smart, C. D., Gardner, S., Gao, J.-L., Ahrens, U., Maurer, R., Schneider, B., Lorenz, K.-H., Seemuller, E., Harrison, N. A., Namba, S., and Daire, X. 1994. Phylogenetic relationships of plant pathogenic MLOs established by $16 \mathrm{~S} / 23 \mathrm{~S}$ rDNA spacer region. IOM Lett. 3:228-229.

19. Lee, I.-M., Dane, R. A., Black, M. C., and Troxclair, N. 2001. First report of an aster yellows phytoplasma associated with cabbage in southern Texas. Plant Dis. 85:447.

20. Lee, I.-M., Davis, R. E., and GundersenRindal, D. E. 2000. Phytoplasma: Phytopathogenic mollicutes. Annu. Rev. Microbiol. 54:221-255.

21. Lee, I.-M., Gundersen-Rindal, D. E., and Bertaccini, A. 1998. Phytoplasma: Ecology and genomic diversity. Phytopathology 88:1359-1366.

22. Lee, I.-M., Gundersen-Rindal, D. E., Davis, R. E., and Bartozyk, I. M. 1998. Revised classification scheme of phytoplasmas based on RFLP analysis of $16 \mathrm{~S}$ rRNA and ribosomal protein gene sequences. Int. J. Syst. Bacteriol 48:1153-1169.

23. Lee, I.-M., Martini, M., Bottner, K. D., Dane, R. A., Black, M. C., and Troxclair, N. 2003. Ecological implications from a molecular analysis of phytoplasmas involved in an aster yellows epidemic in various crops in Texas. Phytopathology 93:1368-1377.

24. Marcone, C., Ragozzino, A., and Seemuller, E. 1997. Detection and identification of phytoplasmas infecting vegetable, ornamental and forage crops in southern Italy. J. Plant Pathol. 79:211-217

25. Nielson, M. W. 1979. Taxonomic relationships of leafhopper vectors of plant pathogens. Pages 3-27 in: Leafhopper Vectors and Plant Disease Agents. K. Maramorosch and K. F. Harris, eds. Academic Press, New York.

26. Ploaie, P. G. 1981. Mycoplasmalike organisms and plant diseases in Europe. Pages 61-104 in: 
Plant Diseases and Vectors. K. Maramorosch and K. F. Harris, eds. Academic Press, New York.

27. Salehi, M., Heydarnejad, J., and Izadpanah, K. 2005. Molecular characterization and grouping of 35 phytoplasmas from central and southern provinces of Iran. Iranian J. Plant Pathol. 41:62-64.

28. Salehi, M., and Izadpanah, K. 1992. Etiology and transmission of sesame phyllody in Iran. J. Phytopathol. 135:37-47.

29. Schneider, B., Seemuller, E., Smart, C. D., and Kirkpatrick, B. C. 1995. Phylogenetic classification of plant pathogenic mycoplasmalike organisms or phytoplasmas. Pages 369-379 in: Molecular and Diagnostic Procedures in Mycoplasmology. Vol. I. S. Razin and J. G. Tully, eds. Academic Press, New York.

30. Seemuller, E., Marcone, C., Lauer, U., Ragozzino, A., and Göschl, M. 1998. Current status of molecular classification of the phytoplasmas. J. Plant Pathol. 80:3-26.

31. Siddique, A. B., Agrawal, G. K., Alam, N., and Krishan Reddy, M. 2001. Electron microscopy and molecular characterization of phytoplasmas associated with little leaf disease of brinjal (Solanum melongena L.) and periwinkle ( $\mathrm{Ca}$ tharanthus roseus) in Bangladesh. J. Phytopathol. 149:237-244.

32. Smart, C .D., Schneider, B., Blomquist, C. L., Guerra, L. J., Harrison, N. A., Ahrens, U., Lorenz, K. H., Seemuller, E., and Kirkpatrick, B. C. 1996. Phytoplasma-specific PCR primers based on sequences of 16S-23S rRNA spacer region. Appl. Environ. Microbiol. 62:29882993.

33. Tran-Nguyen, L., Blanche, K. R., Egan, B., and Gibb, K. S. 2000. Diversity of phytoplasmas in northern Australian sugarcane and other grasses. Plant Pathol. 49:666-679.
34. Vibio, M., Bertaccini, A., Lee, I.-M., Davis, R. E., and Clark, M. F. 1996. Differentiation and classification of aster yellows and related European phytoplasmas. Phytopathol. Mediterr. 35:33-42.

35. Wang, K., and Hiruki, C. 2001. Use of heteroduplex mobility assay for identification and differentiation of phytoplasmas in the aster yellows group and the clover proliferation group. Phytopathology 91:546-552.

36. Wang, K., and Hiruki, C. 2001. Molecular characterization and classification of phytoplasmas associated with canola yellows and a new phytoplasma strain associated with dandelions. Plant Dis. 85:76-79.

37. Zhang, J., Hogenhout, S. A., Nault, L. R., Hoy, C. W., and Miller, S. A. 2004. Molecular and symptom analyses of phytoplasma strains from lettuce reveal a diverse population. Phytopathology 94:842-849. 